Marianna Ansiliero de Oliveira Coelho

Analysis of pneumatic structures considering nonlinear material models and pressure-volume

coupling

TESE DE DOUTORADO

DEPARTAMENTO DE ENGENHARIA CIVIL

Programa de Pós-Graduação em

Engenharia Civil 
Marianna Ansiliero de Oliveira Coelho

\section{Analysis of pneumatic structures considering nonlinear material models and pressure-volume coupling}

Thesis presented to the Programa de PósGraduação em Engenharia Civil of the Departamento de Engenharia Civil, PUC-Rio as partial fulfillment of the requirements for the degree of Doutor em Engenharia Civil.

Advisor: Prof. Deane de Mesquita Roehl Co-Advisor: Prof. Kai-Uwe Bletzinger

Rio de Janeiro July 2012 


\section{Marianna Ansiliero de Oliveira Coelho}

\section{Analysis of pneumatic structures considering nonlinear material models and pressure-volume coupling}

TESE DE DOUTORADO

Thesis presented to the Programa de PósGraduação em Engenharia Civil of the Departamento de Engenharia Civil, PUC-Rio as partial fulfillment of the requirements for the degree of Doutor em Engenharia Civil.

Prof. Deane de Mesquita Roehl Advisor Departamento de Engenharia Civil — PUC-Rio

Prof. Kai-Uwe Bletzinger Co-Advisor Lehrstuhl für Statik — Technishe Universität München

Prof. Ruy Marcelo de Oliveira Pauletti Departamento de Engenharia de Estruturas e Fundações - USP

Prof. Luiz Eloy Vaz Departamento de Engenharia Civil — UFF

Prof. Paulo Batista Gonçalves Departamento de Engenharia Civil - PUC-Rio

Prof. Raul Rosas e Silva Departamento de Engenharia Civil - PUC-Rio

Prof. José Eugenio Leal Coordinator of the Centro Técnico Científico - PUC-Rio 
All rights reserved.

\section{Marianna Ansiliero de Oliveira Coelho}

The author is graduated in Civil Engineering from Universidade Estadual do Oeste do Paraná - UNIOESTE in 2005, she obtained the degree of Mestre in Civil Engineering at PUC-Rio in 2007.

Bibliographic data

Coelho, Marianna Ansiliero de Oliveira

Analysis of pneumatic structures considering nonlinear material models and pressure-volume coupling/ Marianna Ansiliero de Oliveira Coelho; advisor: Deane de Mesquita Roehl; co-advisor: Kai-Uwe Bletzinger - 2012 .

142 f. il. (color.); $30 \mathrm{~cm}$

Tese (Doutorado em Engenharia Civil) - Pontifícia Universidade Católica do Rio de Janeiro, Departamento de Engenharia Civil, 2012. Inclui bibliografia.

1. Engenharia Civil - Tese. 2. Estruturas pneumáticas. 3. Modelos de material. 4. Método dos elementos finitos. 5. Acoplamento pressão-volume. 6. Grandes deformações. 7. Material NURBS. I. Roehl, Deane de Mesquita. II. Kai-Uwe Bletzinger. III. Pontifícia Universidade Catôlica do Rio de Janeiro.

Departamento de Engenharia Civil. IV. Título. 


\section{Acknowledgements}

I would like to thank my mother Lourdes, my father Eduardo, my siblings Anna Carolina, Edson and Daniele to be always on my side giving me support, tenderness and love.

I especially thank my husband Alvaro, for patience, care, support, love and for accepting the challenge to live in Germany.

Furthermore I would like to acknowledge my advisor Deane for the dedication, incentive, patience, friendship during the development of my thesis and specially the support for me to do the sandwich $\mathrm{Ph} . \mathrm{D}$. in Germany.

I also would like to express my gratitude to my co-advisor Herr Bletzinger for the support and wonderful reception in the Lehrstuhl für Statik at Technische Universität München.

I would like to express my acknowledgement to the professors and employees of the Department of Civil Engineering of the Pontifícia Universidade Católica do Rio de janeiro for the support and help.

I also thank the colleagues of the Lehrstuhl für Statik for the pleasant living and help, and the friendships made during my stay in Germany.

Sincere thanks to my friends in Brazil that however distant they were, they gave me strength and support.

Finally I would like to thank DAAD, CNPq and CAPES for the financial support and specially DAAD for the welcome in Germany. 


\section{Abstract}

Coelho, Marianna Ansiliero de Oliveira; Roehl, Deane de Mesquita; Bletzinger, Kai-Uwe. Analysis of pneumatic structures considering nonlinear material models and pressure-volume coupling. Tese de Doutorado - Departamento de Engenharia Civil, Pontifícia Universidade Catôlica do Rio de Janeiro,

In this work a study of pneumatic structures considering pressure-volume coupling under plastic and viscoplastic material behavior is developed. Pneumatic structures are membrane structures acted on by air or gases stabilized by tension. These structures are lighter than conventional structures resulting in economic structural solutions. They present also some characteristics that contribute to the sustainable development, such as the utilization of natural lighting and ventilation and its possibility of reuse. When pneumatic structures are subjected to external loads these structures present both internal pressure and volume variation. This coupling is one of the objects of the present work. Analytical solutions are developed to describe this coupling. In conventional finite element systems this coupling is not considered. A formulation for pressure-volume coupling by closed chambers is included in the framework of a finite element large strain model. The variety of material models implemented has the purpose to cover the behavior of the many kinds of membrane materials used in pneumatic structures. In the literature the study of the membrane materials for pneumatic structures focuses on experimental analysis. Membrane material models are incorporated in the finite element model for small and large strains. The constitutive material models considered in this work are hyperelastic, elastoplastic and elastoviscoplastic. The onset of large strains is enclosed. A new material model based on NURBS surfaces is proposed an validated on hand of experimental results and classic material models. In this work emphasis is given to the material ETFE (Ethylene tetrafluoroethylene), which is widely used in pneumatic structures. The models developed here, such as the pressurevolume coupling and the material models, are implemented in finite elements on the program used in the Static Chair at TUM (Technische Universität München), which is called CARAT++ (Computer Aided Research Analysis Tool).

\section{Keywords}

Pneumatic structures; Material models; Finite element method; Pressurevolume coupling; Large strains; NURBS material 


\section{Resumo}

Coelho, Marianna Ansiliero de Oliveira; Roehl, Deane de Mesquita; Bletzinger, Kai-Uwe. Análise de estruturas pneumáticas considerando modelos não lineares do material e o acoplamento pressão-volume. Tese de Doutorado - Departamento de Engenharia Civil, Pontifícia Universidade Catôlica do Rio de Janeiro.

Neste trabalho um estudo de estruturas pneumáticas considerando acoplamento pressão-volume e modelos constitutivos plásticos e viscoplásticos são desenvolvidos. Estruturas pneumáticas são estruturas de membrana sobre as quais atuam pressão de gases estabilizadas por tensões de tração. Essas estruturas são mais leves que estruturas convencionais resultando em soluções mais econômicas. Elas possuem ainda algumas características que contribuem para um desenvolvimento sustentável, como a utilização de luz natural e ventilação e a possibilidade de reutilização. Quando as estruturas pneumáticas são submetidas a cargas externas, essas estruturas apresentam variação da pressão internal e do volume. Este acoplamento é um dos objetos de estudo do presente trabalho. Soluções analíticas são desenvolvidas para descrever este acoplamento. Em programas convencionais de elementos finitos esse acoplamento não é considerado. Uma formulação para o acoplamento pressão-volume para câmaras fechadas é incluído no modelo de elementos finitos com grandes deformações. A variedade de modelos de material implementados tem a finalidade de abranger o comportamento de muitos tipos de materiais de membrana usados em estruturas pneumáticas. Na literatura o estudo dos materiais de membrana para estruturas pneumáticas tem foco na análise experimental. Modelos para material de membrana são incorporados no modelo de elementos finitos para pequenas e grandes deformações. Os modelos constitutivos considerados neste trabalho são hiperelástico, elastoplástico e elastoviscoplástico. A ocorrência de grandes deformações é incluída. Um novo material baseado em superfícies NURBS é proposto e validado com base em resultados experimentais e modelos clássicos de materiais. Neste trabalho ênfase é dada ao material ETFE (Etileno tetrafluoretileno), o qual é amplamente usado em estruturas pneumáticas. Os modelos desenvolvidos aqui, como o acoplamento pressão-volume e os modelos de materiais são implementados em elementos finitos no programa usado na cadeira de estática das construções da TUM (Technische Universität München), chamado CARAT ++ (Computer Aided Research Analysis Tool).

\section{Palavras-chave}

Estruturas pneumáticas; Modelo de material; Método dos elementos finitos; Acoplamento pressão-volume; Grandes deformações; Material NURBS 


\section{Contents}

1 Introduction $\quad 15$

$\begin{array}{lll}1.1 & \text { Membrane structures } & 15\end{array}$

$\begin{array}{lll}1.2 & \text { Pneumatic structures } & 16\end{array}$

$\begin{array}{lll}1.3 & \text { Formfinding } & 24\end{array}$

1.4 Cutting patterns 26

1.5 Wrinkling in membranes 27

$\begin{array}{ll}1.6 \text { Objective } & 28\end{array}$

$\begin{array}{lll}1.7 & \text { Thesis outline } & 29\end{array}$

2 Mechanics of membranes $\quad \mathbf{3 0}$

2.1 Kinematics 30

$\begin{array}{ll}2.2 \text { Strain measure } & 31\end{array}$

2.3 Stress measure 33

2.4 Membrane formulation 33

3 Membrane Material Models $\quad 43$

3.1 Small strains - Elastoplasticity 43

3.2 Small strains - Elastoviscoplasticity 51

3.3 Large strains - Hyperelasticity 56

$\begin{array}{ll}3.4 & \text { Large strains - Elastoplasticity }\end{array}$

3.5 Large strains - Elastoviscoplasticity 65

4 Material model based on NURBS $\quad \mathbf{6 6}$

4.1 Nonuniform rational B-Spline curves and surfaces 67

4.2 Linear elastic material model based on NURBS (LE-NURBS) 75

4.3 Material model based on NURBS for principal directions (PD-NURBS) 76

$\begin{array}{ll}4.4 \text { Data fitting } & 79\end{array}$

4.5 Validation examples $\quad 80$

5 Pressure-Volume Coupling $\quad \mathbf{8 8}$

5.1 Numerical analysis model for one chamber $\quad 88$

5.2 Multichambers structures 93

5.3 Analytical solution for a circular inflated membrane 93

5.4 Comparison of analytical and numerical analysis 103

6 Examples of pneumatic structures and material models for membranes $\mathbf{1 0 8}$ 
$\begin{array}{lll}6.1 & \text { ETFE-Foils } & 108\end{array}$

6.2 Uniaxial and biaxial test by ETFE-foils 114

6.3 ETFE-Foil modeled with PD-NURBS 116

$\begin{array}{lll}6.4 \text { Burst test } & 119\end{array}$

6.5 Air cushion with single and double chamber 123

$\begin{array}{ll}6.6 & \text { Lyon confluence cushion (C) } \\ & 127\end{array}$

7 Conclusions and Suggestions for future works 134

7.1 Membrane material models 134

7.2 Pneumatic structures with pressure-volume coupling 135

$\begin{array}{lll}7.3 & \text { Suggestions for future works } & 136\end{array}$

8 References 142 


\section{List of Figures}

Figure 1.1 - Pneumatic structures in man's body: (a) Red blood cells, (b) lung

Figure 1.2 - Calceolaria - Inflated flower

Figure 1.3 - Inflated cushions (a) 3-D overview of irregular shaped ETFE cushions used in facade assembly (source: Watts [10]), (b) Testing of full-scale mock-ups (source: LeCuyer [11]), and (c) Rigid edge detail (source: Watts [10])

Figure 1.4 - Distant Early Warning (DEW) line (source: Canadian military journal [13])

Figure 1.5 - Allianz Arena in Munich

Figure 1.6 - Distribution of pneumatic structures with inflatable cushions in terms of continent and country (source: Moritz [15])

Figure 1.7 - Cutting patterns of six-point tent (source: Linhard [31]) 26

Figure 1.8 - Building process of six-point tent (source: Linhard [31]) 27

Figure 1.9 - Influence of pattern definition on membrane structures (source: Linhard [31])

Figure 1.10 - Principle states of membranes: (a) reference, (b) taut, (c) and (d) wrinkle, and (e) slack (source: Jarasjarungkiat et al. [36])

Figure 1.11 - Wrinkled membrane (source: Wong and Pellegrino [37])

Figure 2.1 - Successive deformations of a continuous body

Figure 2.2 - Multiplicative decomposition of the deformation gradient (source: Souza Neto et al. [40])

Figure 2.3 - Membrane coordinates

Figure 2.4 - Triangular elements: (a) linear and (b) quadratic

Figure 2.5 - Quadrilateral elements: (a) linear and (b) quadratic

Figure 3.1 - Plane stress state (source: Souza Neto et al. [40])

Figure 3.2 - Experimental data from uniaxial and biaxial test of ETFE and adjusted von Mises yield curve

Figure 3.3 - General return mapping schemes. Geometric interpretation:

(a) hardening plasticity and (b) perfect plasticity (source: Souza Neto et al.[40])

Figure 3.4 - Mesh, geometry and boundary conditions of a perforated rectangular membrane 
Figure 3.5 - Load versus edge displacement

Figure 3.6 - Phenomenological aspects: uniaxial tensile tests at high temperature (a) Strain rate dependence, (b) Creep, and (c) Relaxation (source: Souza Neto et al. [40])

Figure 3.7 - Force versus displacement curve of a perforated rectangular membrane: (a) $\epsilon=1.0$ and (b) $\epsilon=0.1$.

Figure 3.8 - Square sheet with a circular hole (a) undeformed sheet mesh with applied load (b) diplacement result in y direction with deformed sheet in a scale of 1:1.

Figure 3.9 - Load-displacement curves of stretching of a square sheet

Figure 3.10 - Results of the square sheet with a circular hole: (a) normal stress in $\mathrm{x}$, (b) normal stress in y, (c) shear stress, (d) normal strain in $x,(e)$ normal strain in $y$, and (f) shear strain

Figure 3.11 - Force versus displacement on the free edge of a perforated rectangular membrane

Figure 3.12 - Stress versus strain for numerical analysis with large and small strains

Figure 4.1 - Example of a B-spline surface (source: Piegl and Tiller [73]) 70

Figure 4.2 - Geometry construction of a NURBS curve (source: Piegl and Tiller [73])

Figure 4.3 - NURBS surface: (a) Control points net (b) biquadratic NURBS surface (source: Piegl and Tiller [72])

Figure 4.4 - NURBS surfaces for stresses and strains for LE-NURBS material: (a) stresses in direction 11 and strains in directions 11 and 22, (b) stresses in direction 22 and strains in directions 11 and 22 and, (c) NURBS curve for stresses in direction 12 and strains in direction 12 .

Figure 4.5 - Mesh, boundary conditions and applied load for the quadrilateral example

Figure 4.6 - NURBS surfaces of stresses and strains in principal directions for NeoHookean material: (a) stresses in direction 1 and (b) stresses in direction 2.

Figure 4.7 - Displacement results in y direction: (a) undeformed membrane, (b) conventional material model, and (c) PD-NURBS material model.

Figure 4.8 - NURBS surfaces with stresses and strains in principal directions for the Mooney-Rivlin material: (a) stresses in direction 1 , and (b) stresses in direction 2. 
Figure 4.9 - NURBS surfaces for stresses and strains in principal directions for elastoplastic material: (a) stresses in direction 1, and (b) stresses in direction 2.

Figure 4.10 - Displacements in y direction: (a) conventional material model and (b) PD-NURBS material model.

Figure 4.11 - Stresses in y direction: (a) conventional material model and (b) PD-NURBS material model.

Figure 5.1 - Surface under pressure loading.

Figure 5.2 - Radial and circumferential coordinates, vertical deflection, and radial displacement of a circular membrane

Figure 5.3 - Mesh for a circular inflated membrane.

Figure 5.4 - Comparison between a mesh with linear and quadratic elements for applied external pressure values of $150 \mathrm{kPa}$ and $300 \mathrm{kPa}$.

Figure 5.5 - Comparison between Hencky's and Fichter's solution for applied external pressure values of $150 \mathrm{kPa}$ and $300 \mathrm{kPa}$.

Figure 5.6 - Fichter's solution and numerical results without pretension and $\kappa=0$ for applied external pressures values of $150 \mathrm{kPa}$ and $300 \mathrm{kPa}$.

Figure 5.7 - Comparison between the numerical solution with a pretension of $1 \mathrm{kPa}$ for $\kappa=0$ and $\kappa=1$ for applied external pressure values of $150 \mathrm{kPa}$ and $300 \mathrm{kPa}$.

Figure 5.8 - Analytical and numerical solution with a pretension of $1 \mathrm{kPa}$ and $\kappa=1$ for an applied external pressure values of $150 \mathrm{kPa}$ and $300 \mathrm{kPa}$ : (a) deformed configuration and (b) pressure volume curve.

Figure 5.9 - Analytical and numerical solution with a pretension of $10 \mathrm{kPa}$ and $\kappa=1$ for the applied external pressure values of $150 \mathrm{kPa}$ and 300kPa: (a) deformed configuration and (b) pressure volume curve.

Figure 5.10 - Analytical and numerical large strains solution without pretension and $\kappa=1$ for applied external pressure values of $150 \mathrm{kPa}$ and $300 \mathrm{kPa}$ : (a) deformed configuration and (b) pressure volume curve.

Figure 6.1 - Etylene Tetrafluoroetylene chemical structure 108

Figure 6.2 - Eden Project in the United Kingdom 
Figure 6.3 - Stress-strain curve of semi-crystalline thermoplastic material with schematic representation of the tensile specimen in different steps (source: Ehrenstein [83])

Figure 6.4 - Stress-strain curve: (a) tensile stress vs. strain and (b) compressive stress vs. strain (source Properties Handbook of Tefzelß[54])

Figure 6.5 - Stress-strain curves for cyclic test: (a) $-25^{\circ} \mathrm{C}$, (b) $0^{\circ} \mathrm{C}$, (c) $+23^{\circ} \mathrm{C}$ and $(\mathrm{d})+35^{\circ} \mathrm{C}$ (source: Moritz [15])

Figure 6.6 - Yield stress and strain versus temperature performed by Moritz [15]

Figure 6.7 - Test curves from DuPONT ${ }^{T M}$ [54]: (a) tensile strength vs. temperature and (b) ultimate elongation vs. temperature

Figure 6.8 - Creep test in DuPONT ${ }^{T M}$ Tefzel 200 Flexural [54]

Figure 6.9 - Poisson ratio versus stress for different values of temperature (source: Moritz [15])

Figure 6.10 - Mesh, geometry and boundary conditions for the biaxial test 114

Figure 6.11 - Stress versus strain for small and large strains

Figure 6.12 - Stress versus strain for experimental results and numerical results with small and large strains for the biaxial loading in the proportion of $1: 1$

Figure 6.13 - Stress versus strain for experimental results and numerical results with small and large strains for the biaxial loading in the proportion of 2:1

Figure 6.14 - NURBS surface with experimental data

Figure 6.15 - NURBS surfaces of stress and strain in principal directions for von Mises material: (a) stresses in direction 1 and (b) stresses in direction 2.

Figure 6.16 - (a) Burst test and (b) deformation process (source: Schiemann [84])

Figure 6.17 - Geometry, mesh and boundary conditions for the burst test performed by Schiemann

Figure 6.18 - Pressure versus displacement results for the specimen V28 [84]; linear (T3) and quadratic (T6) triangular membrane elements.

Figure 6.19 - Pressure versus displacement results for the specimen V28 [84]; step length of 60 and 100.

Figure 6.20 - Pressure versus displacement results for the specimen V28 [84]; large strain, and small strain material models. 
Figure 6.21 - Deformed configuration of the specimen V28 [84] and numerical model with large strains for pressure states 1 and 2.

Figure 6.22 - Stress versus strain curve in y direction

Figure 6.23 - Deformed inflated circular membrane with the out of plane displacement: (a) point 1 and (b) point 2

Figure 6.24 - Undeformed cushions: (a) upper and lower membranes of single chamber cushion and (b) upper, middle and lower membranes of double chamber cushion

Figure 6.25 - Cushion dimensions and formfinding shape

Figure 6.26 - Single chamber cushion deformation under external load

Figure 6.27 - Volume versus internal pressure for the single chamber structure

Figure 6.28 - Two chambers deformation under external load

Figure 6.29 - Volume versus internal pressure for two chambers

Figure 6.30 - out of plane displacement versus load

Figure 6.31 - Lyon confluence cushion structure: (a) top view and (b) bottom view

Figure 6.32 - Geometry of the triangular cushion

Figure 6.33 - Mesh of the cushion structure: (a) and (c) without cutting patterns (b) and (d) with cutting patterns.

Figure 6.34 - Flat patterns of the triangular cushion.

Figure 6.35 - Von Mises stress distribution on the cushion structure with pressure-volume coupling: (a) without cutting patterns, (b) with cutting patterns.

Figure 6.36 - Strain in principal directions 1 on the cushion structure with pressure-volume coupling: (a) without cutting patterns, (b) with cutting patterns.

Figure 6.37 - Strain in principal directions 2 on the cushion structure with pressure-volume coupling: (a) without cutting patterns, (b) with cutting patterns.

Figure 6.38 - Stress versus strain for triangular cushion with PD-NURBS material.

Figure 6.39 - Stress versus strain for triangular cushion with elastoplastic material with small strains.

Figure 6.40 - Internal pressure versus volume for the triangular cushion. 


\section{List of Tables}

Table 1.1 - Membrane materials used in pneumatic structures. (source Gómez-González et al. [12]) 24

Table 4.1 - Material properties of quadrilateral membrane example 80

Table 4.2 - Maximum error of the PD-NURBS for rectangular membrane $\quad 82$

Table 4.3 - Displacement residuum for $15 \times 15$ to $100 \times 100$ control point net.

Table 4.4 - Maximum error of PD-NURBS material with surfaces generated by control point nets $20 \times 20$ to $100 \times 100$ for the square perforated example

Table 4.5 - Material properties of the perforated membrane example 85

Table 4.6 - Maximum error of the PD-NURBS for perforated membrane $\quad 87$

Table 6.1 - Material properties of ETFE-foils 114

Table 6.2 - Relative error of biaxial test for the PD-NURBS material 118

Table 6.3 - Material properties of specimen V28 121

Table 6.4 - Global convergence of the displacement residuum at the critical pressure for step length values of 60 and 100.

Table 6.5 - Material properties of the ETFE-foil 129

Table 6.6 - Maximum result values for the triangular cushion 131 